\title{
Erratum to: A Historical View on Mental Illness in Commercial Aviation: The Crash of Japan Airlines 350
}

Daniela Schmid

\section{Erratum to: \\ Chapter "A Historical View on Mental Illness in Commercial Aviation: The Crash of Japan Airlines 350" in: N. Stanton (Ed.): Advances in Human Aspects of Transportation, AISC 786, https://doi.org/10.1007/978-3-319-93885-1_9}

In the original version of the book, the underline in Table 1 content of chapter "A Historical View on Mental Illness in Commercial Aviation: The Crash of Japan Airlines 350" has to be removed. The erratum chapter and the book have been updated with the change. 